\title{
Discussion on the Reform of Wuhan "North Hankou" International Commodity Trading Center and Its Circulation Mode
}

\author{
Xiaojun Zhang \\ Wuhan Technology and Business University \\ Hubei Business Service Development Research Center \\ Wuhan, China
}

\author{
Xinyu $\mathrm{Hu}$ \\ Wuhan Technology and Business University \\ Hubei Business Service Development Research Center \\ Wuhan, China
}

\begin{abstract}
As a new model of Wuhan's commercial circulation industry, "North Hankou" is not only a new growth pole of regional economic development, but also a special region of export-oriented economic development in Wuhan. Therefore, it is helpful for Wuhan to build an international trading city and promote Hubei's first rise in the central region. In this paper, based on the construction of the exhibition center, trading center and distribution center of Wuhan North Hankou imported commodities, as well as the development target of the largest inland trade and investment expo center, its significance, effects and corresponding countermeasures are analyzed.
\end{abstract}

Keywords-wuhan; "north hankou"; imported commodities; circulation pattern; internationalization

\section{INTRODUCTION}

Throughout the territory of China's history, Wuhan has become a brisk business card in the interior of the mainland due to its unique geographical conditions and the advantages of trade and circulation. "North Hankou", as the growth pole and the extension zone of the development of modern commercial trade in Wuhan, should also become a microcosm of Hubei to undertake the eastern industrial transfer and reform the traditional commercial circulation mode.

"North Hankou" International Commodity Trading Center is located in the "Golden Triangle" zone among Wuhan Tianhe International Airport, Wuhan North Railway Marshalling Station and Wuhan Yangtze River Xingang. Therefore, it is positioned as big Wuhan's "Pudong". In the process of becoming an international window for Wuhan to opening to the outside world and connecting with the world in Wuhan, as a convenient and universally accessible commerce platform with preferential policies, "North Hankou" International Commodity Trading Center is very

The Project Supported by Hubei Province Education Department of Humanities and Social Science Project (2014): Developing the Free Trade Zone in the Middle Reaches of the Yangtze River ---A Study on the Construction of Wuhan Xingang Free Trade Zone (Project number: 14G475), scientific research project of CICMLB: China Inland Free Trade Zone: A Study on the Construction of Wuhan Xingang Free Trade Zone (Project number: 2011A201312). noticeable, which is like the pearl in the window and the flagship sailing in the sea of business.

\section{THE NECESSITY AND PRACTICAL SIGNIFICANCE OF ESTABLISHING THE INTERNATIONAL COMMODITY TRADING CENTER IN "NORTH HANKOU"}

Wuhan is located in the Central Plains. As one of the hub cities in China, Wuhan is characterized by a large urban framework, more population and resources, convenient transportation of railways, highways, waterways and aviation extending in all directions. The establishment of the "North Hankou" International Commodity Trading Center coincides with the time. However, since the establishment of "North Hankou", it has a deep impact on the traditional business model, such as the pace of development is not so fast, and its due advantages are far from being played out. The main reasons are as follows:

\section{A. "North Hankou” Lacks New Formats}

By the end of 2013, "North Hankou" had started the construction of 9 specialized markets, including 6 operating markets, 2 building materials industrial parks, 2 logistics parks and 5 large municipal facilities. "North Hankou" has a good momentum of development, but it also faces fierce market upgrade competition from Yiwu, Wenzhou and other places. There is no way out for "North Hankou", if it simply copies the Hanzheng Street model. Therefore, it must carry out business transformation and upgrading, and closely integrate with the virtual market, modern capital markets and overseas markets so as to establish a new form of comprehensive development with the international cohesion of circulation, manufacturing, warehousing and finance.

\section{B. “North Hankou” Lacks Internationally Renowned Brands}

Although there are international well-known brands, such as Playboy menswear flagship store etc., it suffers from the problems of imitated brands and rule-bending act. There are many individual operation modes for international brands, but the proportion of franchisees and direct stores is 9:1. The franchisee lacks long-term plan, coupled with the extensive 
management, there is a wide range of losses. Whether it is relative to the prestigious "Canton Fair", or compared to Zhejiang Yiwu International Trade City, which is known as "small commodity ocean, a shopper's paradise", the popularity "North Hankou" International Commodity Trading Center is relatively low. Instead of becoming a business card of China's inland market, it is still in the period of growth. Thus, the lack of international brands is an important obstacle for "North Hankou" to go global.

\section{C. "North Hankou" Lacks the Leading Position in the Midwest Market}

If the Yangtze River economic belt is likened to a giant dragon, Hubei is the dragon waist, which plays an important supporting role in the development of the whole Yangtze River Economic Belt. At present, cities from the upper and lower reaches of the Yangtze River Economic Belt, such as Shanghai, Chongqing, Ningbo; and the cities from the central region, such as Changsha, Hunan and Hefei, Anhui have set up the "international commodity exhibition trading center" and the "cross-border e-commerce service pilot park" and other high standard trade centers in the integrated free trade zone. Taking Chongqing International Exhibition and Trading Center as an example, the overall selling price of imported wines, sunglasses, kitchenware and fresh food in the trading center is on average 20\%-30\% lower than the market price. Therefore, it is obvious that "North Hankou" has no obvious competitive advantage and leading position in the Midwest.

\section{D. “North Hankou”Lacks International Standards and Commercial Channels}

Even though the specialized market groups of "North Hankou" include international stores, such as the international wholesale city, International shopping street and colorful MINI mall, it has not yet come into line with the real consumer groups at home and abroad, and the channels are sluggish. "North Hankou" International Commodity Trading Center is positioned as the fourth generation of new wholesale market, which is a key project supported by the Ministry of Finance and the Ministry of Commerce, but the traditional business model has a deep impact and a strong taste. Currently, in addition to the gradual expansion of local consumer groups, there are about 6,000 foreign-funded enterprises, and more than 1,500 economic and technical experts work in Wuhan every year. In Wuhan, the proportion of expatriates living in the long-term is $0.5 \%$, reaching nearly 10,000 people. In the next few years, nearly 50 countries will set up consulates in Wuhan, so Wuhan will become the R \& D center and the head office of many multinational corporations. Moreover, more overseas people will come to Wuhan to start their own businesses and live here. In this way, they will create huge consumer groups in the areas of eating, living, traveling, shopping, and entertainment. Wuhan international trade service is indispensable. However, owing to "North Hankou" lacks its docking business channels, it cannot make the best use of the function.
The above factors make "North Hankou" become the bottleneck of the development and reform of Wuhan's modern trade industry, and its advantages are far from being played.

\section{EFFECT ANANLYSIS OF ESTABLISHING "NORTH HANKOU " INTERNATIONAL COMMODITY TRADING CENTER}

"North Hankou" International Commodity Trading Center (hereinafter referred to as the center) is an advanced concept of drawing on international and domestic large-scale commercial and trading markets, attaching importance to import trade, improving the circulation system, and building radiating a professional, fashionable, brand oriented, modern and international trading center for inland areas. It has attracted the attention and esteem of the import and export enterprises in Hubei. The center is created to change the influence of traditional circulation mode of "North Hankou", and achieve the main carrier of integrated development: Business flow-Logistics-Logistics- Information flow. Its effects should not be underestimated.

\section{A. It is Beneficial to Change the Situation of Imperfect Import Market of "North Hankou"}

The center needs to expand foreign trade; build four service systems of E-business, finance, logistics and warehousing; strive to build a world-class logistics platform; invite a large number of buyers from all over the country and around the world to carry out centralized purchasing; form a large-scale procurement center; give full play to the advantages of low cost, well-developed network operators and stable customers; expand foreign trade business for "North Hankou", construct Hubei import and export demonstration base so as to build a platform with three major functions: The first is to create a global import and export commodity display trading center platform with "excellent quality at a fair price". The second is to establish a trading platform that combines inland goods trade and service trade. The third is to build the import and export trade information public service platform.

\section{B. It is Conducive to Boosting the Facilitation of International Trade in Wuhan}

At present, Wuhan is actively docking with the free trade zone in the coastal areas and carrying out inland FTA pilot reporting. The establishment of "North Hankou" International Commodity Trading Center is Wuhan's main breakthrough in the construction of the free trade zone. It can break down some of the policy constraints in cross-border trade, the bottleneck of internal introduction and external integration, and promote the innovation elements such as capital flow, information flow, business flow and logistics to get together in "North Hankou" from a higher level and wider field of degree, develop the headquarter economy through the market. Moreover, it can make the people of Wuhan to participate in the reform of international trade facilitation at home so as to share the "feast" brought by the reform. 
C. It is Advantageous to Bring Wuhan's Unique Geographical Advantages into Play

Wuhan is an important node connecting the "Yangtze River Economic Belt" and "Maritime Silk Road" and "Land Silk Road", which is unique in the country. The center is located in the golden node of strategic resources of three transportation hubs in Wuhan, namely aviation, railway and port etc. Wuhan Air City, Hengdian Marshalling Station and Yangluo Deepwater Port just surround it in the center. The center will give full play to Wuhan's advantages of linking the region to rivers and seas; integrate entity management, network sale and modern logistics system; build the central largest import product exhibition center and cross-border ecommerce marketing center; comply with the residents of the escalating consumer demand, and allow everything from Southeast Asia, Africa and South America to be sold here so as to create a large platform that can experience high quality and inexpensive goods all over the world without going abroad for domestic operators and consumers.

\section{It is Helpful to Tap the Potential of Wuhan Foreign Trade Business Entity}

In the context of a downturn in developed economies abroad and the upgrading in the consumption-driven of domestic economy, it is necessary to integrate and make use of the market resources of the foreign trade business entity in Wuhan, and organize import and export of foreign milk powder, red wine, coffee, olive oil and other bulk commodities in batches selectively so as to maximize the expertise of foreign trade business entity who is good at international trade. Meanwhile, it needs to strengthen the coordinated development of domestic trade and foreign trade. With trade as support and logistics as a carrier, it needs to integrate into the consumption area; open the "sunroof" of import commodity transaction marketing and radiate the role of the center to Europe, America and the Asia Pacific Region.

\section{E. It is Conducive to Enjoying a Series of Policies of the State to Support the Rise of the Central Region}

In recent years, the national strategies begin gathering in Wuhan intensively, such as "The Strategy of the Rise of Central China", "National Central City of the Central Region, the Yangtze River Economic Belt Strategy", etc. "Stabilizing exports, expanding imports and reducing surplus" has been identified as the overall plan for the development of foreign trade. With the adjustment of China's trade policy, more large-scale imports have been given a new mission, the establishment of "North Hankou" International Commodity Trading Center will take the initiative to respond to the state's policy of encouraging import expansion so as to win dividends brought by the interaction of economic factors such as funds, commodities, information and labor in the Wuhan metropolitan area.
IV. OBJECTIVES AND SUGGESTIONS OF ESTABLISHING "NORTH HANKOU” INTERNATIONAL COMMODITY TRADING CENTER

"North Hankou" not only belongs to "big Wuhan", but also belongs to Hubei. Moreover, it belongs to the Yangtze River Economic Belt and even China. The establishment of "North Hankou" International Commodity Trading Center is a new breakthrough, which plays a positive role in seizing Hubei's strategic opportunity of "The Belt and Road", promoting the opening and the transformation, and accelerating the construction of inland open economy Heights. The specific contents should include "five centers" and "five promotions", and it gives support in terms of policy promotion and implementation measures.

\section{A. Build the Largest International Commodity Trading Center in the Province, Make the Commercial Scale of Hubei Bigger and Stronger}

Compared with the developed coastal areas, due to slow transformation of the operational mechanism and the heavy historical burden of enterprises, Wuhan's large trade wholesale enterprises and professional market development is relatively backward, and the scale is limited. On the basis of the existing commercial resources of "North Hankou" and the popularity of Wuhan, it needs to strengthen the display function of the international commodity trading center, optimize the display layout, enrich varieties and innovative display methods so as to build a perennial display platform for international commodities that is the largest in Hubei Province and has great influence in China. Furthermore, it can make the scale and influence of Hubei commercial circulation industry in the aspects of government efficiency, service level, rule by law environment, social credit environment and foreign investment policy.

\section{B. Unites Create a Regional International Trading Center,Improve the Radiation Force of Commercial Circulation Industy in Huber}

The core of the construction of international trading center is to realize the modernization, high-end and agglomeration of Hubei's commercial circulation industry by strengthening the linkage of import and export transactions; become the breakthrough and growth point of the innovation of Hubei commercial circulation mode; promote the coordinated development of large state-owned, private and foreign retail businesses in Hubei and accelerate the formation of a modern pattern of commercial and trade circulation. While promoting trade at the exhibition, it needs to fully exert and expand the trading functions of the center's regional import commodities, promote the "North Hankou" market continues to extend outward to the second and third tier markets and coastal markets and build a regional trading platform with strong radiation force so as to provide a good foundation for promoting international trade cooperation, improving the level of import development, optimizing Hubei's commercial circulation environment and developing business resources. 


\section{Equations Build a National Cross-border E-commerce Test Platform, and Implement the Development Mode of Internet Plus Foreign Trade}

By taking the cross border trade e-commerce service as an opportunity and Wuhan free trade zone and trading center as the base of linkage, it needs to pilot the relevant policies first, implement $\mathrm{O} 2 \mathrm{O}$ development model and build import cross-border e-commerce test platform. At the same time, relying on Hubei international e-commerce application platform, through international payments and international transport links, it not only makes the enterprise foreign trade more convenient and more efficient, but also can be extended to individual consumers, which makes "online buying" more secure and import trade more convenient.

\section{Build the Largest Inland International Commodity \\ Distribution Center, Realize the Model of "Tri- standards" for Trade}

It needs to actively cultivate and rely on the economic development of Wuhan Metropolitan Area; seize the opportunity for Wuhan to apply for the free trade zone; create a commodity trade exhibition platform that integrates "display, trading and information"; actively encourage SMEs to take part in the construction of "North Hankou" International Commodity Trading Center through participation in shares, contracts, mergers, acquisitions, chains, trusteeship and franchising, so that "North Hankou" will not only become an import commodity distribution center, an inland distribution center for import commodities and an inland commodity export and transshipment center to Europe and Asia, but also become a model of "trade environment facilitation, trade diversification and trade service specialization" in the circulation mode innovation.

\section{E. The Largest Inland Trade and Investment Expo Center, form a Win-win Cooperation Mechanism between Industry and Enterprise}

The importance and promotion of the construction of the international commodity trading center will play an exemplary role in building a complete commercial enterprise credit system in "North Hankou", regulating the order of commercial operation, optimizing the commercial legal environment and guiding the circulation of foreign trade enterprises, and improving the cooperative relationship with the manufacturing enterprises. The construction of the center will highlight the feasibility, internationalization, guidance and interaction. By taking the industry transfer and investment trade promotion as the main line, and with information exchange, exhibition, project promotion, cooperation and discussion and thematic forums as the main content, it needs to promote Wuhan's overall docking with domestic and foreign markets, as well as capital and resources. All kinds of enterprises enjoy mutual benefit and win-win results and form a good circulation development mechanism, thus making an economic contribution to open up a new situation in Hubei's commercial circulation and enterprise development.

\section{CONCLUSION}

In the future, "North Hankou" International Commodity Trading Center will become the largest inland trading platform with diversified circulation function, network trade, brand management and internationalized development, and it has no less than 10 foreign public service platforms, 5001000 foreign trade enterprises, 50000-100000 jobs, and the output value of more than ten billion dollars target. Along with our country economy is about to enter the "13th FiveYear" period, "North Hankou" is at the critical period of completing the leap from quantity accumulation to quality, the construction of the international commodity trading center will give "North Hankou" soaring wings to accomplish great achievements in terms of innovative business models.

\section{REFERENCES}

[1] Xiong Jie. On the Development Strategy of "North Hankou" Commerce Logistics Hub, Logistics Technology, 2014, pp.37-40.

[2] Wu Hao. Zall Holdings Try to Build a Domestic Demand Trading Platform Cluster, Changjiang Daily, 2013-06-28.

[3] Hu Siyong. The First Wholesale City of "North Hankou" Opened to Create New Heights of Wuhan Business, Hubei Daily, 2009-12-31.

[4] Yang Guanghua. "North Hankou" International Commodity Trading Center Laid the Foundation Stone, Changjiang Daily, 2007-11-12.

[5] Yue Qiaohong, Zhang Jiahua. Port Logistics Development Experience at Home and Abroad. Hubei Daily, 2009-05-06. 